\title{
The Principles Of The Farewell Pilgrimage Sermon Are The Basis Of The Objectives Of (Al-Sharia) Islamic Law
}

\author{
Mohammad Ibrahim Abu Jraiban \\ Faculty of Rahma College, Al-Balqa Applied University \\ m.abujraiban@bau.edu.jo
}

\begin{abstract}
It became clear to us that what is meant by the knowledge of "the objectives of the law" is that knowledge leading to the knowledge of the goals, meanings and purposes of the provisions of the texts of Sharia, which the wise law has observed, including the legal rulings that achieve the interests of the people. Because the scholars rolled up and circled the depths of the texts, and dealt with research and analysis, and guided to realize its essence. Some of them called it the term objectives and some of them dealt with the term virtues and psychological ailments, and what follow from that of the meanings that indicate chastity and transcendence. Within this section, the sermon came to the farewell pilgrimage, to serve as a general declaration to humanity of the rulings it included, the circumstances and conditions that he wore, and the lofty faults and meanings that resulted from them. They have become human rules and moral standards. It is seen by everyone who aims to achieve good and human happiness. The significance of that prophetic sermon also lies in its complete consideration of the goals and objectives of the various Sharia, with its focus on caring for and achieving the most important of those objectives. It is necessary from them.
\end{abstract}

Keywords:

farewell, sharia, psychological ailments, legal rulings

Article Received: 18 October 2020, Revised: 3 November 2020, Accepted: 24 December 2020

\section{Introduction:}

For from the kindness of God Almighty, His care for people, and His honoring of them over all other creatures, I entrust in them some of the characteristics that qualify them to receive His Laws, glory be to Him. So the messengers sent them, revealed books to them, and guided them to touch the true religion and its rulings.

God Almighty has sealed his laws and messages with the Sharia of Islam. He concluded his prophets and messengers with Muhammad, may God bless him and grant him peace, and the mercy of God was manifested in His servants, and His kindness towards them, and in pursuit of the intended purpose of the guidance of Sharia. Islam tended to educate individuals so that they would be a source of good for their community, and not a source of evil for people. He guided them to virtuous principles and values, to elevate their souls and enjoy their life in this world, and to walk towards the afterlife according to a comprehensive divine approach, and to rid themselves of evils and the rest of grievances and what follows that of defect in homelands and corruption in life. Then, the farewell argument and its facts came, events, meanings and lessons. To chart a lofty approach, and a shift in the principles that dominated people for a period of time.

The Messenger, may God bless him and grant him peace, declared the principles of life and its sound approach in his unique sermon, which was his last sermon at that time and place, in which he explained the principles of truth, equality, and human dignity. It also showed the foundations of Islam and its great principles; of achieving the necessities of his purposes.

Those purposes that people have agreed to consider, preserve and care for; because it is the basis of their existence; and their preservation is necessary for their survival and an investigator of the wisdom of their existence as successors to God and executors of His order. That sermon was a comprehensive system and a complete constitution, including the legislative connotations 
and realistic rulings it contained. It seeks to found a nation that will lead the troubled, reckless world to a place of permanent stability and warm sanctuary of safety.

\section{The research importance}

The importance of research is evidenced by the statement of lofty human interests. Which was mentioned in the sermon of the farewell pilgrimage, which is one of the most important objectives of Islamic law, including the provisions it included seeking to protect man, and all his concerns that were adopted by the divine laws and the high provisions?

\section{The research problem}

Through the emergence of dangers and difficulties threatening human life, which seek to destroy his structure and the heart of his life; To return to the world of chaos and darkness that prevailed in the pre-Islamic era. Through this, the research problem appears, which must be met by powerful legislation to overcome and reform

As with the above, the study problem becomes clear through the following questions:

1- What are the main legal objectives included in the sermon of the Hajj Farewell, and what is its importance in the country?

2- What is the mechanism by which the Messenger may God bless him and grant him peace, was able to achieve the purpose of selfpreservation?

3- What are the benefits that accrue to the jurists and seekers of knowledge through knowledge of the objectives of Sharia?

Previous studies

I found studies that dealt with this topic, or an aspect of it, including:

1 Ali Oglu's study entitled: "The Objectives of Islamic Law and Their Employment in Solving Contemporary Problems"

2- Nafez Abu Ubaidah's study entitled: "Sharia measures to preserve the mind"

3- A study by Omar Muhammad Jablah entitled: "The Objectives of Islamic Law"
4- The study of Muhammad Al-Zuhaili entitled "The Objectives of Sharia is a Basis for Human Rights"

These studies have shown the importance of knowledge of the objectives and the need to know them for science students, jurists, and researchers in the human sciences in general, and Sharia sciences in particular, and their positive role in demonstrating the greatness of the Sharia, and its ability to control matters, confront calamities and crises, and solve problems.

\section{The research Method}

Adopting the methodology based on extrapolating judgments and facts, gathering evidence, analyzing it and drawing lessons from it; All this falls within the scope of the descriptive approach that controls these studies

\section{Meaning of al-Sharia objectives:}

Language: the intent is the intention, and the intent is the intent of the thing, it is said: the intent is the intention. Intention and purpose comes in one meaning, and then the intent comes to indicate several meanings, including: adopting a thing, coming to it, heading towards it, and then it comes to the meaning of righteousness, ease, justice and mediation. She says: I meant him and I meant one meaning to him, and I meant a poem. The intention of a thing is not to exaggerate it, in other words, between extravagance and lowliness. 1

Sharia in the language refers to "religion, religion, the method, the Sunnah, and the way, and it also refers to the sources of water and its source, which is intended by the drinkers." 2

The meanings of this language are closely related in the following idiomatic sense: Because it shows and clarifies what is meant by the street and what is meant by the process of legislating provisions. The principles of righteousness and justice, as well as ease and moderation, are all meanings that the Shari'ah includes from the legislation of rulings.

Idiomatically: the previous scholars among the jurists and the people of origins did not 
deliberately set a specific meaning that controls this science. Rather, they referred to it when they searched the texts and rulings, probed their depths, realized their consequences, and deduced their causes. The issue of knowing the boundaries, highlighting and uncovering terms was not in the first place, or in the top of their research priorities, because understanding and clarity of meaning clogs that up for them. As for contemporary scholars, their approaches to this science have agreed to define it first and clarify what it is intended for. 3

Therefore, the researcher restricts the knowledge of the purposes of Sharia by touching the means leading to knowledge of the noble goals, ends, meanings, and lofty judgment hidden in the texts, which the wise street understood and included those legislative provisions that fulfill the interests of the people.

The general purpose and purpose of the Sharia is to achieve the interests of the people, and this is done by ensuring their necessities, providing them with their needs and completing their improvements. Therefore, every Sharia ruling has what he intended except for one of those three that make up the interests of the people. Because the goal and supreme goal of the Sharia is to achieve the interests of people in this world and the hereafter; By bringing the benefits to them and warding off the disadvantages for them.

Thus, the noble purposes of the Sharia are nothing but their goals and objectives, and all of their features that the scholars observe from enacting rulings for the happiness of people 4 .So what is known is a priori, and it is known that all the provisions of Islamic law were not revealed except to achieve the good and happiness of man, just as Sharia came to take care of his interests in the two worlds, and in this regard Al-Shatibi says: "The laying down of laws is for the interests of the servants both in the immediate and future. He adds, "The tracing of Sharia rulings shows that; in all matters of Sharia, which is indicated by induction. Thus, we conclude that the matter continues in all the details of Sharia."5

God Almighty did not lay down Sharia rulings for us without benefit or purpose. Rather, it was intended to achieve general objectives that meet the interests of the people that are approved by Sharia. An increase in pampering; Ibn alQayyim says: "Any way by which the truth was extracted and by which justice was defined, and judgments must be made according to it and according to it. Roads are means and means that are not intended for themselves, but rather their ends are the purposes, and you will not find one of the ways that prove the truth except that it is a law and a way to indicate it otherwise full. "6

That is why the aim of the Sharia is the advancement of people and their advancement. By bringing their benefits, warding off harm from them, and guiding them to goodness and the ways of guidance. So that they realize the true interests, and thus legal rulings have been set for them to be a guide for them to achieve the goals and objectives, and the principles and branches were revealed to them to achieve the goals, then preserve and properly maintain them, and secure and guarantee them so that they are not attacked.

Those meanings are Sharia; among the scholars are those who take it with the wording of the objectives, and some of them deal with it using the terms psychological virtues. These virtues that go back to the veneration of everything that is venerated, and in this chapter they enter the sections of worship, and what is related to the virtues called chastity, and they are of two types:7

- The virtues contained in restaurants and bars.

- The virtues mentioned in the chapter on mankind.

Some of them are due to achieving justice and repudiation of injustice. They include retribution, punishments, and wars; because it demands justice.

Including the virtues contained in the symptom circle. 
Including the virtues contained in the money section.

Among them are virtues that appear in the doors of the basic meeting in the lives of people and the preservation of its virtues, which are recognized in the name of the leadership 8. In this way, these legal objectives surround what is beneficial to the human being, correct him, achieve his major demands, organize his life, and lead him for good.

\section{Second - The importance of knowing the objectives of the Sharia}

God sent down the law to His servants so that they can refer to it, and you will be their leader and guide for them to win and succeed in both worlds that is why all Sharia is good for human beings, for in it the benefit is achieved and by it the harm is rushed. Bringing benefit and warding off harm are the highest aims of creation, and the righteousness of creation is in the fulfillment of their purpose. Accordingly, the intention of the Shariah from creation is to achieve five things: As Al-Ghazali says: "It is to protect them their religion, their soul, their mind, their offspring, and their money. Everything that includes preserving these five assets is an interest, and everything that misses these five assets is corrupt, and paying them interest." And he adds, "These five assets are preserved in the category of necessities, as they are the strongest ranks of interests."9

These objectives of Sharia achieve a number of benefits, including:

1- Scholars and scholars have insight into the rulings of Sharia and contribute to how to derive rulings. Because God Almighty has made for the legal rulings a set of reasons that the novice student and jurist can see, and thus it helps him to understand the legal rulings and to know them.

2 - Knowing the objectives of the Sharia is also a necessary and important factor for a diligent jurist 10. Because it informs him of knowing the correctness in devising the legal ruling, and thus reassures the world of the safety of what his diligence arrived at.

And people enjoy the shade of the provisions of Sharia, and their understanding of all their conditions.

3- Knowing the purposes of the Sharia increases the understanding of its legal rulings, and helps in deriving rulings from their evidence, and applying them to reality, which helps scholars, preachers, reformers, and other intellectuals, and all the faces of people. Facilitate their affairs, and achieve their goals 11 .

Therefore, from the above, we can realize that the guarantee of these five necessities that a good life needs, and upon which the necessary things and life approaches are based. Have been agreed upon by all the divine laws; Even manmade laws said that they must be preserved and respected, as their prohibition was not permitted in any form of boredom.

Therefore, people's actions and actions that are considered interests are not of the same degree. Rather, it is divided into several sections, which we explain in the following:

Circumstances and position of the farewell pilgrimage sermon

As for the circumstances of the sermon of the farewell pilgrimage, it was distinguished in its impact and impact, and was also distinguished in its temporal and spatial container, and distinguished in its speech, policy-making and objectives. This sermon is full of beautiful lessons and meanings that the Prophet, may God's prayers and peace be upon him, was keen to establish among his companions, to be a guide for them and help them to overcome the hardships that befall them, some of which were leaked from the remnants of the obsolete ignorance. Life and the rituals of the days, and this sermon was at the end of the era of the Prophet, may God's prayers and peace be upon him, as it took place in the ten year of the migration, on the day of Arafah, and in the best parts of the earth. So it was a sermon addressed to all, and inclusive of honorable people, suitable for it to be a general pact 
approved by the nations, and for all people to meet with it, and he, may God's prayers and peace be upon him, began it by saying: "O people, listen to my saying, I don't know why I'm never meeting you with this situation." They have rulings and matters that interest them and elevate their rights at a time when principles and rights are blurred 12.

Sections of the objectives of the total law approved by the sermon and its evidence

First - Sections of legal objectives in general: The scholars are almost unanimous in dividing the objectives of Sharia with regard to the actions of those charged with what those actions include into three sections:

1-Necessities, 2-Needs, 3-Improvements

As for the necessary interests that are the most important axes of the Prophet's sermon in the farewell pilgrimage; It is essential for it to establish the religious and worldly affairs of the people, so that if it is lost, the interests of the people do not follow guidance and integrity, but rather they follow corruption and arrogance. Then chaos reigns, and life systems disrupt; Corruption prevails in the world of people 13.

And in the afterlife, salvation is lost and bliss diminishes, and the evident loss returns to people.

There are five principles of necessities, namely: preservation of religion, preservation of the soul, preservation of the mind, preservation of children and preservation of money14. The Prophet, may God's prayers and peace be upon him, says in his sermon regarding these principles: "Hear my saying, for I don't know that I'm not going to meet you after this year," and he says: "So worship your Lord, pray your fifth, fast your month, pay zakat on your money, and perform the pilgrimage to the house of your Lord .." This feels the importance of receiving and following up to preserve my purpose. Religion and reason that is the subject of assignment, and the basis for scrutiny; So it leads to the correct follow-up, and also says: "Your blood and your money is forbidden to you." This also feels the importance of preserving the purpose of life and money 15 . Because they are the basis for achieving what God desires for his servants by his succession to them in life, and his saying, peace and blessings of God be upon him: "Fear God in women ..." A notification of the importance of preserving the purpose of the offspring and the honor in which the family is strong and extended

The preservation of these five matters is a matter on which there is consensus, and there is no difference in it between the laws, and it is in two matters: the first - fixing its pillars and observing them in existence, and the second - preventing corruption and defect in them, and observing them from the side of nothingness, and preserving religion is by establishing belief in the souls, and what is attached to it From the legislation of worship and provisions related to its defense 16; Such as the legislation of jihad, and souls are preserved by fulfilling the necessities that establish them, protecting them and preventing attacks, and enacting penalties that protect them; Like Qisas, and the preservation of the mind is its search for research, consideration and sound thinking, and the legalization of the ban on drinking intoxicants. Because reason is the basis of every matter in which interest is achieved, and because its difference leads to great evils, and the preservation of the offspring is by preserving women and honor and forbidding adultery and forbidding it, and legislating the punishment for the punishment for adultery and defamation, and preserving money after urging the permissible methods of seeking. Two things from the side of nothingness:

The first of them - by prohibiting usury and the injustice it leads to, and giving the guarantee to the transgressor. Because with money livelihood.

The second of them, cutting off the thief's hand. Apply theft limit

When Islam legitimizes these necessary interests for the people to ensure their creation, preservation and protection; He has fulfilled the 
people's necessities; So that their lives should be straightened according to what God Almighty commanded, and what the Messenger, may God bless him and grant him peace, declared in his sermon17.

Second - Evidence for considering legal objectives: Preserving these objectives is one of the most important objectives of Shari'a. Therefore, legal evidence was available to safeguard them. Especially the necessary ones that the nations have taken care and consideration, and they are the five necessities, and evidence indicating their observance is as follows:

1. From the Holy Qur'an the words of God Almighty :( Say Come recite what is forbidden to your Lord, you do not join none and dutiful to your parents do not kill your children from pauperism we give you and them not come near them as immoral and belly do not kill the soul which Allah has forbidden except with the truth. That is the Allah advised you by that you understand $\{151\}$ not come near the orphan's wealth, but one that is better until it reaches its peak Fulfill double balance with justice, not MANDATE breath but can interpretation of the meaning, even if a kinship and the covenant of Allah fulfilled. That is the Allah advised you if you may recall) [Al Anaam: 151 -152]

In the noble verses, the care of Sharia is shown in preserving these essentials. It came in the preservation of religion, the Almighty forbade him from polytheism with him in belief and worship, and it came in the preservation of the soul that the Almighty forbade him from killing children, as well as killing the soul. And it came in preserving the offspring that the Almighty forbade committing the immoralities of fornication, Because adultery is one of the most serious and dangerous immorality18. In keeping the money there was a prohibition by God Almighty from consuming the money of orphans, and this was expressed by proximity. To be a sleeper in the realization of the seriousness of the matter; except that the treatment be kind. As for the preservation of the mind, this is inferred from the set of rulings that indicate the preservation of necessities, because whoever spoils his mind is not a guardian of the rest of the other necessities 19.

2. From the Sunnah of the Prophet, the Messenger of God, may God's prayers and peace be upon him, said: "Avoid the seven evils. They said: O Messenger of God " 20.

This evidence reinforces these sources of his sermon: Those that include basic rights for human beings, so these matters should not be violated as mentioned in the hadith, and this makes us aware of the greatness of these matters and their danger, and that they are not permissible to be tolerated, and that excessive ones corrupt life and security.

As for the obligatory interests: Those are the things and actions that people need. For expansion, and lift the distress leading to embarrassment and hardship. Its loss does not disrupt life as necessary interests. But it is a site for people in embarrassment, distress and distress, or as Al-Shatibi says: "If you do not take into account the taxpayers will receive the critical sentence and hardship, but this severity does not amount to the amount of normal corruption occurring in the public interest. 21" The same is apparent in his sermon, may God's prayers and peace be upon him: "The blood of the Jahiliyyah is fabricated, and the first blood I put from our blood is Ibn Rabia's blood." And if the blood is placed, then blood money takes its place, then it is one of the intended needs for the preservation of souls, as well as his saying: "Whoever has trust, let him lead it to the one who entrusted him with it." The allocation of the woman and the fulfillment of her right is a notice to establish a solidarity society.

As for ameliorative interests; It will be obtained by adopting the good of customs, values and virtues; It is required by chivalry and etiquette, and its owner avoids profane conditions and the rest of the debased, which the good people's temperament and their preponderant minds denounce. Covering the private parts, 
avoiding impurities, taking decorations to the mosques, rest of the etiquette of eating, the etiquette of maintaining public security, the prohibition of extravagance and mischief, the nonsale of impurity, and the preference of pasture and water unless a person adopts it with his effort and money, and the prohibition of killing boys, women and monks in jihad, and the prohibition of acting with the dead The enemies and their treachery. And everything in it is the perfection of the nation, preserving its dignity, and beautifying it in accordance with the morals 22 .

If improvements in people's lives are lost, they do not disrupt their lives; Like losing essentials, and not feeling embarrassed and hardship like losing necessities. But they may feel inferior and ashamed, and their instinct refuses to do so. Because improvements are complementary to the necessity and the needs at the highest level and complete the condition, and what is evidenced by the preservation of this rank in the sermon of the farewell pilgrimage is his saying, may God bless him and grant him peace: "Satan despairs to be worshiped with your earth, but if he obeys other than that, he is satisfied with what you move of your deeds, beware of him." The abominations of deeds that violate the chivalry and rebuke the devil, so avoiding them is perfect for virility and the best of morals 23 .

There is also an arrangement of the necessary interests between them; So the interest of preserving the religion precedes the self, the interest of preserving the soul precedes the mind, the interest of preserving the mind precedes the offspring, and the interest of preserving the offspring over money. With this methodical approach to considering interests, their role in maintaining security emerges, and in this regard Al-Taher bin Ashour says: "The general purpose of legislation is to preserve the system of the Islamic nation, and to sustain his goodness in the goodness of the dominant, which is the type of man. His hands are an asset of the world in which he lives. "
Taking into account these interests in the (Ummah) Islamic nation is tantamount to preserving its existence and security, and losing that inevitably leads to the disruption of that life, and the spread of corruption that leads to the annihilation of the existence of this world and the loss of the hereafter, and for this it has not lost sight of the Prophet, may God's prayers and peace be upon him, in that great scene and the multitude of people 24.

And for the great role of these interests and the extent of their importance in achieving security in societies; The Fiqh Councils decided to adhere to it and to take into account its content while researching and devising legal rulings. It was stated in the decisions of the Islamic Fiqh Council emanating from the Organization of the Islamic Conference in its eighteenth session held in Malaysia:

First - The purposes of Sharia are the meanings, judgment and goals that the street intends to achieve from enacting rulings, in order to bring the interests of the servants in this world and the hereafter 25 .

1. A comprehensive examination of the texts and provisions of Sharia.

2. Considering the objectives of the Sharia among the preponderant among the various jurists.

3. Insight into the consequences of actions when applying Sharia rulings.

Second - The importance of implementing the objectives of the Sharia in applying Sharia rulings to facts and calamities for contemporary financial transactions and others to achieve distinction in Islamic formulas and products, and their independence from traditional formulas 26.

This sermon sought to establish the purposes of security, which includes security over religion, security over the soul, security over the mind, security over children, and security over money, in a world rife with turmoil, conflicts, wars, and the resulting corruption.

Therefore, general research in the scope of legal objectives makes security considerations a 
self-evident connotation, which must be pursued in the field of these sciences. Accordingly, some scholars have increased the necessary interests. Preserving the state, security and human dignity, to be consistent with that in that sermon, who considered the issue of community security intended for its own sake, so it must be preserved when he said: "O people, listen to my words and make sense of it. You know that every Muslim is a brother of a Muslim, so do not oppress yourselves." So the establishment of brotherhood and love among people, and denying injustice from them; It enhances the values of security in society, those values that are considered essential, according to the recent determination of the intention27.

Sections of the essential objectives mentioned in the sermon:

First - Among the first of these objectives is preservation of the debt, which is one of the first necessary matters; This requires the survival of its meanings and facts, and their teaching to people; As the Messenger of God, may God's prayers and peace be upon him, did in his sermon in which he explained the major features of religion 28. Of your deeds: "In that is the preservation of religion in the souls, because they were reminded to meet God and warn them against the schemes of Satan. This is the best way to preserve religion and adhere to it. The prophetic instruction also came in his sermon that it is necessary to preserve the rituals of the religion and its major features, because with it the religion is preserved, and on this the honorable Companions walked; Because religion is one of the most important things on which people gather and manage their lives29. It is the beliefs and acts of worship, and the rest of the rules and laws that God Almighty legislated to regulate people's relationships with each other and their Lord.

That is why Islam has legislated to create and establish religion from the side of existence, the rulings of faith, the five pillars on which Islam is built, and all the beliefs and acts of worship that the street intends to establish and establish religion in the hearts, and by following the purposes and provisions by which people are fit 30.

And God Almighty has prescribed for us the means and means that lead to preserving this religion, so that it becomes a rich source of security. People are blessed with that.

Among the most important rulings that Islam legislated to preserve the purpose of the religion from the aspect of nothingness is related to fighting those who turn away from religion and hinder its mission, and it called that jihad. Jihad, which is one of the most important laws of Islam; to protect people, defends them and protects their rights, and in this regard God Almighty says: (Were it not for God to push people against one another, the land would be corrupted, but God is the one who is gracious to the Most High). For through jihad, God preserves the earth from corruption. People keep themselves and their beliefs and their property and God says in another verse :( who have been driven from their homes unjustly only because they believe in God and not God, people pay each other for the silos were demolished and the sale and prayers and mosques mention the name of God and Allah often fight with whom fight for his right and that Allah is strong Dear) [Al-Hajj: 40] That is, if God Almighty had not forcibly pushed people for jihad against people, May the land corrupt, destroy the weak from the people, and disrupt places of worship in all religions, such as silos and sale of Christians, synagogues of Jews, and mosques for Muslims. Jihad was an imperative; because it is a reason for preserving security for people, and preserving homelands and places of worship; which is the symbol of faith.

Islam's interest in jihad is only because it fulfills the great pillar of achieving the goal of security in the homelands. Through it it repels the aggression of the oppressors, and through jihad, the vulnerable people are saved those who cannot deflect injustice and aggression on their own and their homelands 31. Almighty:( and what you are not fighting for God and vulnerable men, women 
and children who say: Our Lord brought us out of this village and its unjust said, and make for us from Thee, and to make us from Thy champion) [Al Nisaa: 75]

And from what was mentioned in this sermon about preserving the purpose of the religion, the Messenger, may God's prayers and peace be upon him, said: "O people, you will meet your Lord, and he will ask you about your deeds." Pray five of you and fast your month, you will enter the paradise of your Lord. "The Messenger, May blessings and peace are upon him, enumerates here the rituals and clear acts of Islam that are the basis of the religion and its resurrection, such as prayer, fasting, zakat, and Hajj, in addition to reminding them of the fundamentals of faith, which are a requirement for preserving the purpose and resurrection of religion as monotheism and belief in the Last Day32.

Islam also sought legislate Hajj rulings to preserve the necessary purpose, which is religion. This is inferred from the saying, peace and blessings of God are upon him: "O people. The rituals of those times are closely related; because some of them are related to the day, some are related to the week, and some are related to months and years; Thus, Islam was not restricted to the rulings of creating and preserving religion. Rather, Allah indicated the Hajj provisions for the maintenance of the religion and its preservation in the best form. So it legalized the concessions in acts of worship, and reminded them of the times, and in this way it will alleviate them, and lift the hardship and embarrassment 33.

The ameliorative provisions were enacted to preserve that necessary purpose as well. This is inferred from the Prophet, may God's prayers and peace be upon him, said: "People, listen and understand my words." (Abu Zahra, Muhammad, The Jurisprudence of the Sira, p. 489) and this is a call for listening and contemplation, that listening is based on freedom and choice, and thus Islam prohibited coercion in religion. Almighty :( There is no compulsion in religion, he said the majority had found it canceled atone idols and believes in
Allah hath grasped the most trustworthy inextricable and Allah is Hearing, Knowing) [AlBaqarah, verse 256]; Because religiosity is a human right that is based on freedom, choice, and personal conviction, and because religion stems from the heart; And there is no one authority over it but the Creator Almighty.

Second - and the second of the essential purposes that must be preserved: What we mean by self-preservation; That is, the human soul, for conservatism is a basic intention of the Sharia. And this is done by protecting it from the side of existence by permitting the good things from eating and drinking and all that is required to ensure their life and survival.

It is also a matter of self-preservation; Preserving human dignity, by preventing defamation and insult. 34So preserving the soul is only through its rise from the side of existence, and whatever deficiency is avoided by reality or expected, and this is done by taking into account it from the side of nothingness, and thus the Messenger, may God's prayers and peace be upon him, says in his sermon: "O people, your blood ... is forbidden as the sanctity of your day." He adds, saying in a way that preserves the soul and defends the unjust norms of the pre-Islamic era, "Every blood that was in the pre-Islamic era is subject, and the first of your blood I put the blood of Ibn Rabia bin Al-Harith bin Abdul Muttalib." The nation is obligated to preserve it; When he begins to apply it to himself and his kinship first, which nullifies the habit of ignorance of revenge and the loss of souls; He declares the abolition of the blood of the pre-Islamic, the first of which is the blood that belongs to him by virtue of kinship.

Islam has prescribed something to protect the soul from the imbalance of reality or expectation of it, by taking into account it from the side of nothingness, then prescribed punishment for the soul, organs and wounds in order to protect it. The Almighty said: (And in stories you have life, $\mathrm{O}$ most of you, perhaps you may fear) (Al-Baqarah: 179) 35 
With our intransigence in protecting the human soul and warding off harm from it, Islam created the crime of murder, and the promise of killing one soul is tantamount to killing all of humanity. God Almighty said: (for that we wrote to the children of Israel that whoever kills the same or corruption in the earth as if he killed all if it is recited saved all the people and I came to them Our Messengers with clear proofs, and that many of them then in the ground for waster) [Al Maada: 32 ], he who kills one soul and violates its sanctity. It is considered as if he killed all people and whoever revives the soul and saves it from perdition; As if he revived all people 36 .

The infallibility and preservation of the soul is a basis in Sharia law, a pure right of God Almighty: (Say: Come recite what is forbidden to your Lord, you do not join none and dutiful to your parents do not kill your children from pauperism we give and them not come near them as immoral and belly do not kill the soul which Allah has forbidden except with the truth. [AlAnaam: 151], it is not permissible to forfeit that right. For this reason, Islam has prohibited the crime of suicide, because human life is not a property of its owner, but a right of God Almighty.

With our persistence in preserving the human soul, Islam has made the crime of premeditated murder one of the greatest sins, and it has promised it. On the authority of Anas, may God be pleased with him, on the authority of the Prophet, may God's prayers and peace be upon him, when he mentioned: "The major sins, or he was asked about major sins, so he said polytheism with God, killing the soul and disobeying the parents, so he said I should not inform you of the greatest sins 37 .

Indeed, Islam has made the human soul inviolable, like the sacred house of God. The attack on the human soul is an assault on the law of God in his creation. The Messenger may God's prayers and peace be upon him, says: "And by whom my soul is in the hand of killing a believer, is greater with God than the demise of the world."
The Messenger, may God's prayers and peace be upon him, explained the severity of the crime of murder, and warned people not to approach it, or to fall into it. In his sermon, as he bids farewell to his nation; On the authority of Abu Bakra, may God be pleased with him, he said: The Prophet, may God's prayers and peace be upon him, addressed the people on the Day of Sacrifice, so he said: "Do you know which day is this? They said: We said God and His Messenger knows best. He said: He kept silent until we thought that he would name it without his name. We said: Yes. He said: Which country is this? We said: God and His Messenger knows best. He said: Is it not in the country? - Meaning the forbidden We said: Yes, O Messenger of God. He said: Your blood, money, and honor, and I share with you is forbidden as the sanctity of your day this day in your month this in Your country this 38.

Have you not reached? We said: Yes. He said: Oh God, bear witness. To inform the absent witness: It is the Lord of an amount of more than he is more aware of so it was, and he said: Do not go back after me as infidels, some of you beating each other's necks.39"

That is why the purpose of Islam is to protect souls is essential, and for its sake it has prescribed rulings that fulfill it, including:

1- Preserving the souls of all citizens of the Islamic State; Because Islam protects the soul except for its right. The Messenger of God, may God's prayers and peace be upon him, says: "It is not permissible to have the blood of a Muslim who bears witness that there is no god but God and that I am the Messenger of God except with one of three: the soul for the soul, the unrighteous, the adulterer, and the apostate from the religion that leaves the group 40."

Islam is subject to the infallibility of a Muslim, and non-Muslims are citizens of the state. Man was protected by his political loyalty to the state, including the self-contract on which his citizenship in the state settled. For the Messenger of God, may God's prayers and peace be upon him, said: "Whoever kills the soul of a treaty will 
not relieve the scent of paradise, and if its scent is to be found in the course of forty years".

The same applies to the trustee: Who enters the Islamic State under the era of safety; Islam has forbidden the loss of himself because the infallibility of the soul is an established right of the human being, as it is safeguarded by virtue of its creation and creation, and it is not permissible except for an urgent matter such as fighting, spoiling the land, or transgressing the lives of others with aggression and injustice 41 .

2- Islam obliged the state to establish all systems to provide security for all members of society in order to achieve security and live in peace for them.

3- Islam requires solidarity among all members of society to spread reassurance between them. The Messenger may God's prayers and peace is upon him, said: "You see the believers in their compassion, friendship and sympathy as the same as the body. If a member complains, the rest of the body will invoke it by staying up late and feverishly 42."

4- Islam legitimizes a person to defend himself if someone unlawfully destroys him who wants to kill him. He may defend himself even if that leads to the killing of the harrow. He is not responsible. For the Messenger of God, may God bless him and grant him peace, said: (Whoever is killed without his money is a martyr, and whoever is killed without his religion is a martyr, and whoever is killed without his blood is a martyr, and whoever is killed without his family is a martyr) 43.

Who is defending himself; And he is killed, then he is a martyr. When he was a martyr, he must kill and fight for those who assault him.

5- Islam allows prohibitions to be taken to preserve life when necessary. It is permissible for a Muslim to eat what God forbade when necessary if he fears that he will perish 44 .

6- Corruption on earth is forbidden, and everything that leads to spreading killing, terrorizing and targeting safe enemies in jihad, and brutal killing and extermination are prohibited, and everything that leads to the eradication of people.

The right to life is attached to the obligation to preserve human dignity. Because man is a creature honored by God Almighty, and this is evidenced by the Almighty's saying: Whatever contradicts this honor is legitimately and de facto rejected 45.

\section{Third: Preserving the mind}

Islam paid great attention to the mind, because it is assigned the responsibility, and it honors the human.

Reason is the subject of assignment, and with it man has risen and becomes qualified to understand the doctrine and bear the legitimate costs. Almighty :( Taking your Lord, the angels said, I will create a Khalifa in the earth, said they you make where the mischief therein and shed blood, while we praise and sanctify you said I know what you do not know) [Al-Baqarah: 30], and the Almighty said :( is the one who made you Khalifa in the earth, it is He disbelieves, so his disbelief is on him, and the unbelievers do not increase their disbelief at the time of their Lord. The Almighty says: 46 "Those who listen to what they say and follow the best of it are those whom God has guided and those of you are the first." (18)

As for those who disagreed with that; $\mathrm{He}$ neglected the mind and disrupted it, or used it in what was useless. Warned him the Koran and described minimal descriptions, he says :( I have urged unto much hell of the jinn and their hearts do not understand them and their eyes do not see them and their ears do not hear by those like cattle, but they misled those are the heedless) [custom: 179] 47.

The mind is the most important tool for knowledge, thinking and consideration. That is why he raised the status of Islam for those who use their knowledge for the advancement of people. God said :( Come security is obedient night pots, fearing the Hereafter and hoping the mercy of his Lord Say: Are those who know and 
those who do not know but remember Ulloa minds) [Cliques: 9].

And the sciences that Islam urged; They are the sciences that are beneficial to people, and include the sciences of religion and the world. The Messenger of God, may God's prayers and peace be upon him, said: "Whoever brings God back with good, he will understand him in religion." This urges people to learn the sciences of religion and delve into them for those who are qualified for that 48 .

As for the field of worldly sciences; Islam has drawn attention to research and contemplation in the fields of the universe. Almighty :( not seen said that God sent down water from the sky to get fruits of different colors and from the mountains of new red white and various colors $\{27\}$ and the people and animals and cattle as well as different colors but fear Allah scientists Allah is Mighty, Forgiving) [creator: 27 and 28).

As a result of these trends, a rising scientific movement appeared in the Islamic State in its prosperous eras, and this was accompanied by an apparent scientific backwardness in Europe at those times. Even in the eighteenth century, Europe viewed mental illness as a result of the domination of an evil spirit over man, and it treated the patient with extreme cruelty in order to remove this evil spirit from him, and in many cases this cruelty led to his death 49 .

Islam has established great principles that establish a scientific renaissance, and keep the mind away from intellectual backwardness. Among these principles are:

1- Islam asks every person to call for an idea to bring scientific proof and clear evidence for his idea. Almighty :( It leaves with God another god, no proof has its said, for he calculated his Lord that he does not succeed unbelievers) [Believers: 117], God as well as the Almighty said, indicating the falsehood of the argument who associate with God following the whims :( security creation, then bring him back and gives From the heavens and the earth, a god with God, say: Bring your proof if you are honest.
2- Calling for the adoption of the scientific method based on sensory evidence and mental consideration. God Almighty says: "And do not stop that which you have no knowledge of, for the hearing, the vision and the hearts of all of those who have memorized the mind of the being.

As for preserving the mind from the side of nothingness, Islam has forbidden to use anything that might corrupt and depart minds. He forbade alcohol and imposed the punishment in it, and sought to preserve the minds of all the (Ummah) Islamic nation, so he resisted the negative phenomena that spread among the (Ummah) Islamic nation's members, such as drugs and the spoilers that fall under it. Such as hashish, opium, and other things harmful to the mind, that was frequently consumed in the fourth century 50 .

As for the pilgrim aspect of preserving the mind; It appears in caring for specialized and rare education that is in the best interest of the nation, directing outstanding students to it, paying attention to scientific research, and encouraging researchers to rely on it. As well as taking care to divide and classify majors, and take into account individual student differences, as well as Islam obliged jurists and diligent people in the field of Sharia rulings the conditions that are observed and considered for fatwa 51.

As for the enhancement aspect of preserving the mind; It appears in Islam forbidding a little alcohol, even if not intoxicated. The Messenger of God, may God's prayers and peace be upon him, said: "Whatever intoxicates a great deal, just a little is forbidden." This is to prevent pretensions 52.

\section{Fourth - preserving Birth :}

The purpose of preserving the offspring is reproduction and procreation to preserve humanity and the continuation of its survival and the preservation of offspring from the side of existence is done according to what God Almighty has prescribed to preserve the soul. Because what is prescribed for self-preservation is the preservation of the offspring; Such as legislation 
on marriage, as well as a good education for children, preserving and caring for the family, and enacting provisions that preserve her safety, preserve her survival and protect her from the challenges she faces; As for preserving offspring from nothing, it is by prohibiting everything that leads to harm to it. Such as fornication, killing of children, deliberate abortion, and advocacy for birth control 53.

And in pursuit of the Islamic Sharia to achieve this objective, it decided provisions, including:

1. It made marriage the only and legitimate way for the continuation and perpetuation of offspring, and forbade every relationship between men and women outside marriage.

The purposes of marriage are many, and in this regard Sheikh Al-Sherbiny says: Doctors said the purposes of marriage are three: preserving the offspring and removing water whose retention is detrimental to obtaining pleasure.

The purposes of marriage are not limited to this limit, but extend to include many types, such as the survival of human descendants, increasing the power of Muslims by increasing their blackness, achieving housing and affection between them, chastening and fortifying both men and women, taking care of their rights, preserving lineages and raising human beings from bestiality.

2. Care and attention to raising children and a righteous family, Ibn Ashour says: "The regularity of the families' affairs in the (Ummah) Islamic nation is the basis of its civilization and the regularity of its university. Therefore, taking care of controlling the family system is one of the purposes of all laws."

And to achieve this important purpose which is a matter of necessities; Sharia has sought to adopt a set of objectives and Hajj provisions that lead to this purpose, such as permitting polygamy, for the sake of proliferation of children and other purposes of marriage.

As for the ameliorative provisions that complement this intention, It appears in mercy, permitting the fiancée to look at, achieving competence between spouses and the rest of family etiquette, as well as cohabitation etiquette. The purpose of preserving children was revealed in the sermon of the Prophet, may God's prayers and peace be upon him, by saying: "O people, fear God among women, for you have taken them with the faithfulness of God and permissible for them to pray with the word of God. The prominent concern, because they are the basis for building the family and empowering it, and they are the main reason for the emergence and resurrection of the goal of preserving children.

By realizing these meanings positively or negatively by Sharia; It will achieve the security of the soul of the individual, the family and society, and this will be reflected in the status of the nation which supports cooperation and stability on the land and its architecture as God Almighty wanted.

\section{Fifth - Preserving Money:}

Saving money from the rules of Sharia colleges due to the necessary department, the Islamic Sharia's view of money appears in its distinct mediation among the various economic opinions in this field, and that when it legislated from the provisions that guarantee the preservation of that money in terms of existence, and the aspect of nothingness 54. As for the aspect of existence, the Sharia has permitted beneficial work and serious endeavor, and it has legalized contracts and transactions that achieve this, and on the aspect of nothingness, the Sharia forbids everything that leads to the destruction of money, its loss and its deficiency. Such as theft, fraud, and dealing with usury, and I was obliged to do so, discretion and guarantee money, in order for it to be realized and money saved.

And Islamic law, through this procedure, has taken a realistic view of money. It is an essential tool for a person who cannot do without it. So it is the sustenance of his life, and the goodness of his livelihood; that is why a person must save it and not lose it. God Almighty says: "And do not give the fools your money that God 
has made for you to rise and provide them with them, and clothe them, and say to them 56 .

God also forbade the Almighty for extravagance and waste of money, he says :( The kinship right and the poor and the wayfarer not squander a waste $\{26\}$ The squanderers are brothers of the devils and Satan was ungrateful to his Lord) [Al -Isra: 26-27] urged God to mediate and moderation when Expenditure, then the Almighty said: "And those who spend they do not spend, nor are they deceived, and between that was support." 57[Al-Furqan: 67]

What is Islam's legislation for transactions between people? Such as selling, leasing, company, and speculation ... except for the purpose of realizing the source of preservation and protection of money, and for this reason the provisions guaranteeing its preservation and resurrection were prescribed. Such as the prohibition of theft, warfare, and necessitated by that limit, just as treason and deceit are prohibited, and everything that leads to consuming people's money unlawfully, and it is also prohibited to destroy the money of others and everything that harms the property of others, just as Islam has legalized stone on fools to conserve funds 58 .

Based on these provisions, the Islamic Sharia, in all sections of transactions and penalties, has preserved money in terms of whether and not Thus, it has developed a clear policy and method for its purposes in preserving money, and this is summarized in considering money as a means of subsistence and fulfillment of needs, and it has pushed people to bring money and obtain it by legitimate means.

The Sharia also warned the human being of the most forbidden methods of collecting money, and guided him to the proper disposition of this money in its distribution and spending. She explained to him everything he needed in that. So man became aware of his matter 59 .

These provisions and those objectives are reinforced; What came in his sermon, may God's prayers and peace be upon him, where he said: "Your blood and your money is forbidden upon you until they receive your Lord ... and every usury is subject - void and canceled - and you have the heads of your money. A good soul from it, "that is an economic and human value that the sermon contained and urged; By demonstrating legitimate ways to bring in money, dispose of it, and spend it moderately 60 .

The conduct of the human being in accordance with the provisions of Islamic law in dealing with money, positive or negative, rather, it is a fundamental factor in achieving social security and economic security in societies 61 .

What is the reason for humanity's misery in this life except because they view money negatively, contrary to the provisions of Sharia and its important purposes. Therefore, the opinions and ideas of the scholars of Sharia had a realistic and positive touch. For the sake of realizing the truth and removing injustice from man, and searching for everything that pleases him and brings him cypress in this world and the next life; That is why these scholars approached the door of the objectives. And their plan was to search it in three categories according to its importance to humans. So that the first of those orders is of origin; these, in turn, consist of five levels intended for humans 62.

So this method was the subject of research among scholars of this art throughout the ages of the scientists in this regard, until scientists came after them and looked at those sciences and decided to develop this science. That is, "knowledge of the objectives", whereby it is freed from the traditional individual view to the collective view that is consistent with the rules of legitimacy in the primacy of the public interest over others 63.

Consequently, calls for renewal emerged, based on the foundation of the overall public interest versus partial individuality, and the field of the science of objectives did not stop to this extent. Some even called for a start in this science. That is, knowledge of the objectives from the five faculties to the four fields, including the field of the individual, the field of the family, the field of 
the nation, and the field of humanity 64 . So that the comprehensive intent of this science is to be realized in preserving man in all his situations and interests, as the sermon called for the farewell argument, which was a general affliction that occurred to save man from all aspects of his interests and situations. Because achieving good for a person, individually and as a group, is the basis of knowledge of the objectives 65 .

Therefore, if we are allowed to take a step forward in this science; We say: It is a science reduced in one area; It is the achievement of goodness, happiness and security for a person in this world and the hereafter, and this is what came clear and we explained in that sermon in which the Messenger of God, may God bless him and grant him peace, bade farewell to his nation.

\section{References:}

[1] Ibn Manzur, Muhammad Ibn Makram, (d.711 AH) Lisan al-Arab, an article Qasid

[2] Ibn Manzoor, Lisan Al Arab, Article Sharia

[3] Al-Fassi, Allal, The Objectives and Honor of Islamic Law, p.7

[4] Al-Shatibi, Abu Ishaq Ibrahim bin Musa (d.790 AH). The approvals in Usul alFiqh, c2 p. 2, Dar al-Fikr edition.

[5] Al-Shatby, approvals, part 2, p. 3.

[6] Ibn Al-Qayyim, Muhammad bin Abi Bakr (d. $751 \mathrm{AH})$. Media of the two sites, C4, p. 303, Dar Al-Ghad Al-Jadid, 1st floor, Cairo, 2009

[7] Al-Zuhaili, Muhammad. The Objectives of Sharia is a Basic for Human Rights, a research in the book, Majallat AlUmmah, issued by the Qatari Ministry of Endowments, No. 87, 1423, p. 67.

[8] Ibn Rushd, Muhammad bin Ahmed (595 AH). Bidaya al-Mujtahid, vol. 2, p. 476, Dar al-Marifa, ed. 4, 1987.

[9] Al-Ghazali, Abu Hamid (505 AH). AlMustasfi, P.
[10] Al-Dahlawi, Ahmad Shah Wali Allah (1762 A.H.), Hajjat Allah Al-Raghira, vol. 1 p. 8, House of Knowledge, Beirut

[11] Ibn Hazm, Jami`al-Sirah al-Nabawiyyah, p. 206

[12] Al-Mubarakfoury, Al-Raheeq AlKhatmum, p. 392

[13] Shatby. Approvals, C2, p. 3.

[14] Ibid, p. 4.

[15] Al-Ma'afari, Ibn Hisham, The Biography of the Prophet, Part 4, p. 141

[16] Al-Shatby, approvals, c2, p. 4

[17] Narrated by al-Bukhari, Muhammad bin Ismail (d. $256 \mathrm{AH}$ ) Sahih al-Bukhari, The Book of Wills, chapter on God Almighty saying that those who eat orphans unjustly. Edition Dar Al-Jeel, Beirut

[18] Al-Mubarakfoury, Al-Raheeq AlKhattum, p. 392

[19] Shatby. Approvals, C2 p.4.

[20] Rida, Muhammad, The Book of Muhammad, may God bless him and grant him peace, p. 347

[21] The previous reference.

[22] Khalaf, Abd al-Wahhab (d.1375 AH) Usool al-Fiqh, p. 203. Dar Al-Qalam Edition, Damascus, 2nd Edition, 1408 $\mathrm{AH}$

[23] Al-Maafari, Abd Al-Malik bin Hisham, (213 AH) Al-Seerah Al-Nabawiyyah, Part 4, p. 141

[24] Ibn Ashur, Muhammad al-Taher (d.1973 CE) Maqasid al-Sharia, p. 273. Edition of Al-Nafaes House, Amman, 1421-2001.

[25] Organization of the Islamic Conference. Resolutions of the Islamic Fiqh Council on Sharia objectives and their role in deriving rulings, held in Malaysia from 24-29 Jumada al-Akhira, 1428 AH, Resolution No. 166 (5/18).

[26] Attia, Jamaluddin. Toward the Activation of Maqasid al-Sharia, p. 154, Dar Al-Fikr Edition, Damascus, 1423-2003.

[27] Ibid., P. 139.

[28] Rida, Muhammad's Book, p. 348 
[29] Al-Maafari, The Biography of the Prophet, Part 4, p. 141

[30] Klaf. Usul al-Fiqh, p. 200.

[31] Rage. Brief Tafsir Ibn Kathir, vol 2, p.91. Dar Al Marifa Edition, Beirut, 2nd Edition, 1986 AD

[32] Al-Mubarakfoury, Al-Raheeq AlKhattum, p. 392

[33] Rida, Muhammad's Book, p. 348

[34] Al-Khudari, Muhammad (d. 1927 A.D.) Usul al-Fiqh, p. 300. The Great Commercial Library edition, Egypt, 6th edition, $1389 \mathrm{AH}$

[35] Khalil, Imad al-Din, A Study in the Prophet's Biography, p. 329

[36] Al-Qurtubi, Muhammad bin Ahmed (d. $671 \mathrm{AH})$, al-Jami 'al-Ahkam of the Noble Qur'an, vol. 3, p. 380, edited by Abd alHamid Hindawi, Modern Library, Beirut, 1427-2006.

[37] Narrated by al-Bukhari in his Sahih, Kitab al-Adab, chapter on disobedience to parents is a major sin.

[38] Narrated by Al-Nasa'i in his Sunan, Dar Al-Kutub Al-Ilmiyya edition, Beirut, Edition 1, 1991 AD, the book The Prohibition of Blood, Chapter of Glorifying Blood, and Abu Abdul Rahman Ibrahim bin Al-Muhajir said: He is not strong.

[39] Narrated by Al-Bukhari, Kitab al-Fitn, chapter on the words of the Prophet, may God's prayers and peace be upon him, "Do not go back after me as infidels who hit each other's necks. See the Biography of the Prophet, by Ibn Hisham, vol. 4, p. 142.

[40] Narrated by al-Bukhari, Kitab al-Diyat, chapter on the words of God Almighty that the soul is for the soul, the eye for the eye, the nose for the nose, the ear for the ear, and the tooth for the tooth.

[41] Narrated by Al-Bukhari, Book of Diyat chapter on the sin of the one who kills a dhimmi without a crime
[42] Al-Derini, Fathi, Characteristics of Islamic Law, p. 250. The Resala Foundation Edition, Beirut, 1st Edition, 1982 AD

[43] Narrated by Al-Bukhari, Book of Literature, Chapter on Mercy for People and Animals.

[44] Al-Tirmidhi narrated it in his Sunan and said a good and authentic hadith, The Book of Diyat, chapter on what came about who was killed without his money, then he is a martyr. Achieving Ahmed Muhammad Shaker, Dar Al Hadith, Cairo

[45] Al-Zuhaili, Muhammad. Examining Maqasid al-Shari'a is a Basis for Human Rights, p. 105

[46] Narrated by Al-Bukhari, The Book of Knowledge is the chapter with which God will return good and understand him in religion.

[47] Zakaria, Fouad. Scientific Thinking, Jordan Ministry of Culture print, p. 36.

[48] Ali, Muhammad, Necessities, needs and improvements, Research and Proceedings of the Twenty-second General Conference, p.5

[49] Ibn Ashour. Maqasid al-Sharia, p. 304.

[50] Atia. Towards Activating Maqasid alSharia, p. 86.

[51] Narrated by Abu Dawood in his Sunan, the book Al-Sharaba chapter forbidding intoxicants. Sunan Abi Dawood, Dar Al Hadith, Cairo, 1st Edition, 1973 AD

[52] Al-Zuhaili, Muhammad. Research entitled: The Objectives of the Sharia, a Basis for Human Rights, p. 108

[53] Ali, Necessities, needs and improvements, p.6

[54] Abu Zahra, Muhammad (d. 1394 AH) Usul al-Fiqh, p. 368. Dar al-Fikr al-Arabi edition

[55] Al-Sherbini, Muhammad Al-Khatib (d.977 AH). Mughni al-Muhtaj, Dar AlFikr Edition, vol. 3, p. 124. 
[56] Al Fawzan, Saleh bin Fawzan. Jurisprudence Summary, p. 578, Dar AlInsirah, Egypt.

[57] Ibn Ashour. Maqasid al-Sharia, p 430.

[58] Attia. Towards Activating Maqasid alSharia, p 151.

[59] Rida, Muhammad's Book, p. 348

[60] Abu Ubaidah, Nafez, Preventive Sharia Measures to Preserve the Mind, Master Thesis from An-Najah University, Nablus, Palestine, page 25, 2011

[61] The noble verses return money to the ummah, so the ummah must preserve it, control methods for disposing of it, and monitor individuals 'behavior in their money. Because saving the sum depends on saving its parts.

[62] Al-Shawkani, Muhammad Ali (d. 1250 AH), Irshad Al-Falahl, p. 216, Dar AlFikr Edition, Beirut

[63] Rida, Muhammad's Book, p. 348

[64] Ibn Ashour. Maqasid al-Sharia, p. 406, where he says: We have to imagine the Islamic nation in the form of a single Muslim individual, so we present its conditions from the rulings as we present the conditions of the individual.

[65] Attia. Toward the Realization of Maqasid al-Sharia, 139. 